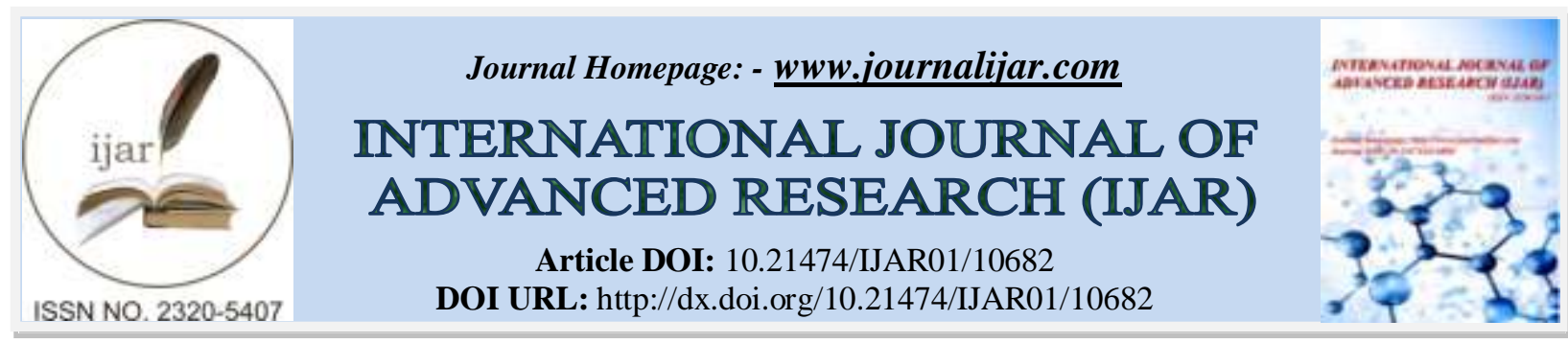

RESEARCH ARTICLE

\title{
STUDY OF CONCRETE COMPRESSIVE STRENGTH BY USING CALCIUM CARBIDE WASTE WASTE AS THE SUBSTITUTION OF CEMENT AND SAND GLASS AS SUBSTITUTION
}

Fahrizal Zulkarnain ${ }^{1}$, Tondi Amirsyah Putera ${ }^{1}$ and Rika Irawan ${ }^{2}$

1. Lecturer in Civil Engineering Program, Faculty of Engineering, University of Muhammadiyah Sumatera Utara.

2. Postgraduate Student in Civil Engineering, Faculty of Engineering, University of Muhammadiyah Sumatera Utara.

\section{Manuscript Info}

Manuscript History

Received: 17 January 2020

Final Accepted: 20 February 2020

Published: March 2020

Key words:-

Compressive Strength Concrete, Waste Glass, Waste Carbide, B3 Waste

\begin{abstract}
As the development of the construction will also increase the use of cement and sand as a material in concrete mixes, and a variety of ways as well as research continues to be done in order to obtain alternative materials, so that the concrete has economic value and environmentally friendly, to the authors conducted tests using waste carbide as a substitute for cement by $7 \%$ and $10 \%$ and the waste glass powder as a substitute for sand by $5 \%$ and $7.5 \%$ in the concrete mix, as well as with the combined use of the two materials is expected to be an alternative material mixed concrete, also reduces the waste that can harm the environment, as well as to can determine compressive strength generated by the material. This research was conducted at the Laboratory of Civil Engineering North Sumatra Muhammadiyah University with methods SNI 03-2834-2000, and quality of concrete plan of $25 \mathrm{MPa}$. Based on the results obtained from the concrete compressive strength test data, the optimal value in waste carbide variation in the amount of $10 \%$, while the value of optimal variation on glass waste of $7.5 \%$. And the mixture of waste carbide combination of $10 \%$ glass waste plus $7.5 \%$ increase in the amount of $4.92 \%$ at the age of 7 days, amounting to $4.87 \%$ at 14 days, and $1.08 \%$ at 28 days, compared with normal concrete. This proves that the carbide waste and glass waste can be a substitution of alternative materials cement and sand on a particular variation.
\end{abstract}

Copy Right, IJAR, 2020,. All rights reserved.

\section{Introduction:-}

\section{Background:}

The growing development is directly proportional to the increasing demand for concrete as a building material that is widely used, and development will continue to grow so does the need for further concrete in the future.

As the development of the construction will also increase the use of cement and sand as a material in concrete mixes, and a variety of ways as well as the study continues with the goal of obtaining a concrete alternative material that has economic value and environmental friendliness.

Corresponding Author:- Fahrizal Zulkarnain

Address:- Lecturer in Civil Engineering Program, Faculty of Engineering, University of Muhammadiyah 
Carbide waste and glass waste commonly encountered in daily life is still not a lot of utilization so that it becomes garbage piling up and be the source of the problem. Waste carbide is B3 waste originating from the welding industry, resulting from the reaction of water with calcium carbide then produce reactor gas acetylene, by attachment of Government Regulation No. 101 of 2014 regarding the management of hazardous and toxic waste carbide and glass waste included in the list of waste Hazardous and Toxic or B3.

Waste Calcium carbide has a chemical composition oxide $(\mathrm{CaO})$, silica $\left(\mathrm{SiO}_{2}\right)$, iron $(\mathrm{Fe})$, aluminum oxide $\left(\mathrm{Al}_{2} \mathrm{O}\right)$, and other chemical elements. It is known that the main elements forming the cement is calcium derived from limestone, So waste carbide is also a cement-forming material (Rajiman, 2015),

Glass waste is waste that are produced from public life, glass waste every day increasing in volume since man much use of glass, some glass waste directly discharged into open land, it is certainly going to pollute the environment in view of the glass is a material that is difficult to decompose or be recycled naturally by nature (Suhartini, 2014), Therefore do an innovation to reduce waste glass, one of which utilize the existing glass waste as one of the concrete mix material. In this case the glass will be used as a partial replacement of fine aggregate in the concrete mix.

\section{Literature:-}

\section{understanding Concrete:}

Concrete is a mixture of Portland cement or other hydraulic cement, fine aggregate, coarse aggregate, and water with or without the added material to form a solid mass(SNI 03-2834-2000), The concrete-forming material is mixed evenly with the specific composition so as to produce a homogeneous mixture that can be poured into the mold to the desired shape. The mixture, when left to experience hardening as a result of a chemical reaction between cement and water that lasts for a long period or in other words the hard concrete mix will increase in line with age.

\section{Waste Carbide:}

Waste carbide is B3 waste originating from the welding industry, resulting from the reaction of water with calcium carbide then produce acetylene gas reactor. Technology and innovation as the development of concrete, carbide waste reduction solution that accumulate in the city of Medan is to conduct reuse (Reuse) that can be used as a building material construction material that is friendly to the environment. The goal is to reduce the B3 waste that can pollute the surrounding environment and realize sustainable development (sustainable construction).

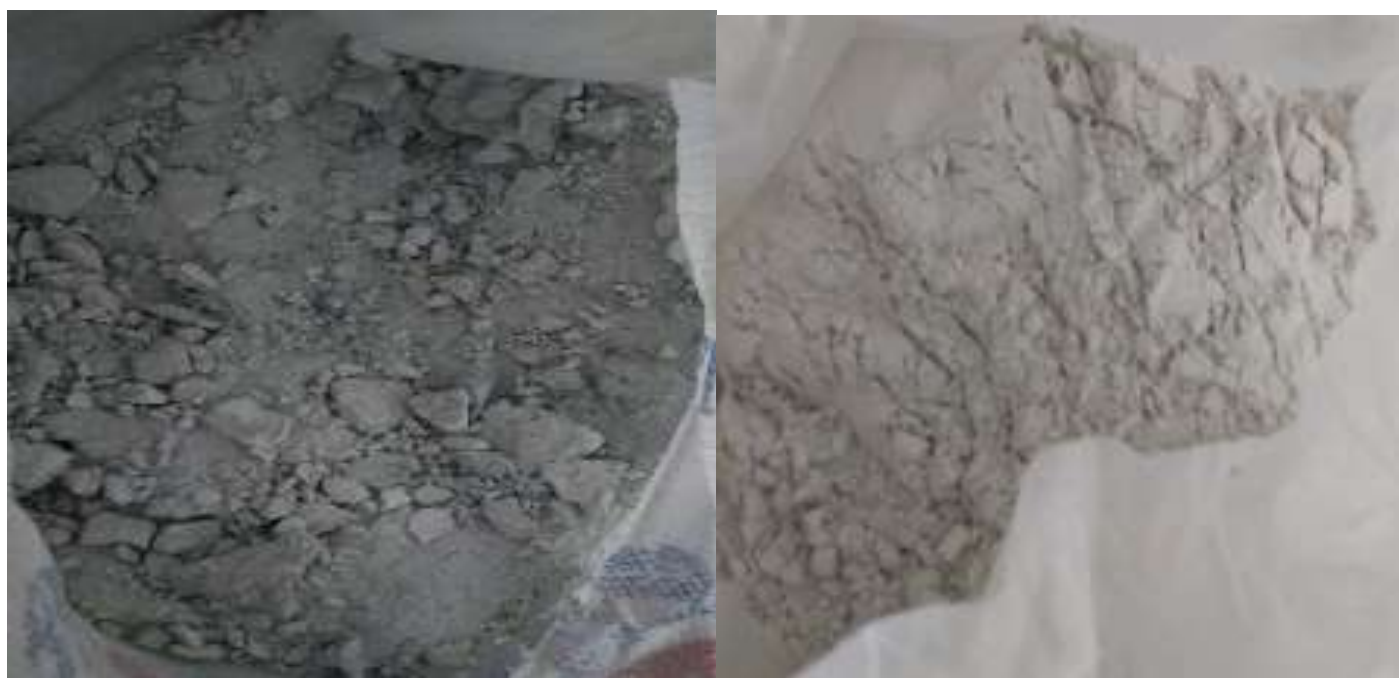

Picture 1:- Waste carbide before and after processing.

Waste carbide used in this study is the result of a welder who then pulverized and sieved through sieve \# 200

Table 1:- The content of waste carbide (Damara, 2018).

\begin{tabular}{|c|c|}
\hline Chemical composition & Ingredients\% \\
\hline $\mathrm{SiO}_{2}$ & 4.3 \\
\hline $\mathrm{Fe}_{2} \mathrm{O}_{3}$ & 0.9 \\
\hline
\end{tabular}




\begin{tabular}{|c|c|}
\hline $\mathrm{Al}_{2} \mathrm{O}_{3}$ & 0.4 \\
\hline $\mathrm{CaO}$ & 56.5 \\
\hline $\mathrm{MgO}$ & 1.7 \\
\hline $\mathrm{SO}_{3}$ & 0.06 \\
\hline $\mathrm{lol}$ & 36.1 \\
\hline
\end{tabular}

\section{Waste Glass:}

Glass is a chemical industry products most familiar with our daily lives. Glass is a substance created by the cooling of molten materials, not crystalline but remains in a hollow shape.

Many things that may potentially benefit from the use of glass as aggregate concrete,(Suhartini, 2014) among others:

1. Having a high level of durability, since glass is a material that does not absorb water.

2. Glass has a high resistance to abrasion and these characteristics are characteristics that are rare in other natural aggregate.
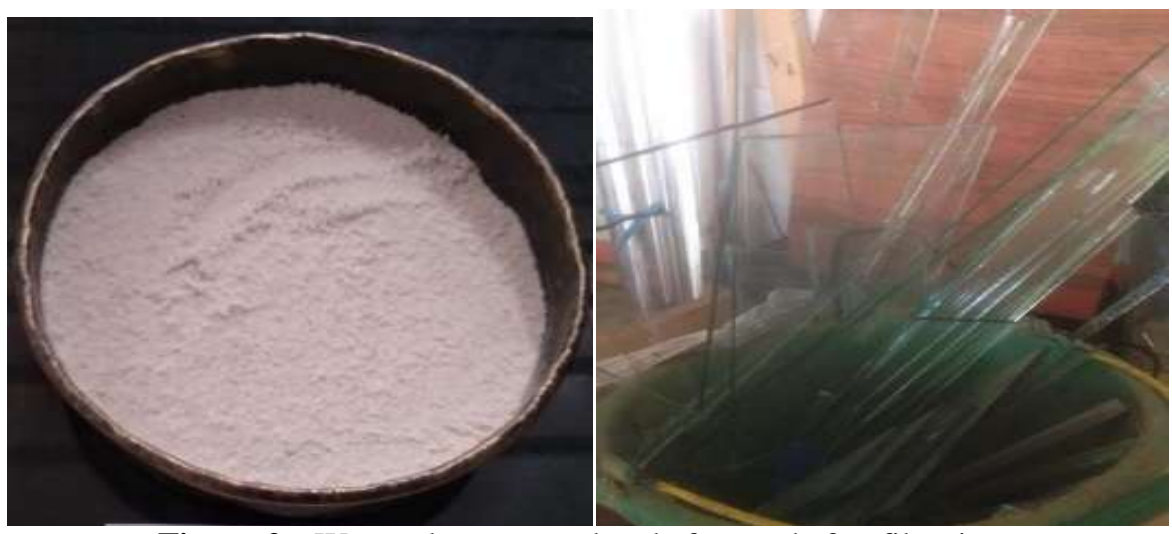

Figure 2:- Waste glass green glass before and after filtration.

Table 2:- Chemical Ingredients glass (Harahap, 2018).

\begin{tabular}{|c|c|}
\hline $\begin{array}{c}\text { Composition } \\
\text { Chemistry }\end{array}$ & $\begin{array}{c}\text { Clear } \\
\text { Glass }\end{array}$ \\
\hline $\mathrm{SiO}_{2}$ & $73,2-73.5$ \\
\hline $\mathrm{Al}_{2} \mathrm{O} 3$ & $1,7-1.9$ \\
\hline $\mathrm{Na}_{2} \mathrm{O}+\mathrm{K}_{2} \mathrm{O}$ & 13.6 to 14.1 \\
\hline $\mathrm{CaO}+\mathrm{MgO} O$ & 10.7 to 10.8 \\
\hline $\mathrm{SO}_{3}$ & 0.2 to 0.24 \\
\hline $\mathrm{Fe}_{2} \mathrm{O}_{3}$ & $.04-.05$ \\
\hline $\mathrm{Cr}_{2} \mathrm{O}_{3}$ & - \\
\hline
\end{tabular}

Waste glass used in this study was is kind of clear glass that is crushed and sieved through sieve no.30 and no.50 disaringan restrained.

\section{Data Analysis And Discussion:- \\ Data Mixed Concrete:}

In this case I will analyze the data that has been obtained as the research proceeds so obtained values of base aggregate examination results are listed in Table 3 below. These data can be used to design concrete mixes (Mix Design) with the required compressive strength of $25 \mathrm{MPa}$ using a method (SNI 03-2834-2000). 
Table 3:- The data base checks.

\begin{tabular}{|c|c|}
\hline Data types & Score \\
\hline The specific gravity of fine aggregate & $2.54 \mathrm{~g} / \mathrm{cm} 3$ \\
\hline Density of coarse aggregate & $2.70 \mathrm{~g} / \mathrm{cm} 3$ \\
\hline Levels of fine aggregate mud & $4.6 \%$ \\
\hline Levels of coarse aggregate mud & $0.88 \%$ \\
\hline Absorption of fine aggregate & $1.73 \%$ \\
\hline Absorption, coarse aggregate & $0.76 \%$ \\
\hline Weight content of fine aggregate & $1.33 \mathrm{~g} / \mathrm{cm} 3$ \\
\hline Weight content of the coarse aggregate & $1.62 \mathrm{~g} / \mathrm{cm} 3$ \\
\hline FM fine aggregate & 2.61 \\
\hline FM coarse aggregate & 7,20 \\
\hline The water content of fine aggregates & $2.21 \%$ \\
\hline The water content of the coarse & $0.53 \%$ \\
\hline aggregate & $23.03 \%$ \\
\hline thirst aggregate & $30-60 \mathrm{~mm}$ \\
\hline Value slump plans & $40 \mathrm{~mm}$ \\
\hline Maximum aggregate size & \\
\hline
\end{tabular}

\section{Planning Results Mixed For The Test Objects:}

Cement : Sand : Stone Broke : Water

$2.37 \mathrm{~kg}: 3.16 \mathrm{~kg}: 6.36 \mathrm{~kg}: 0.90 \mathrm{~kg}$

Based on the above comparison obtained the amount of waste carbide $7 \%$ of cement weight of $0.165 \mathrm{~kg}, 10 \%$ calcium carbide waste of $0.237 \mathrm{~kg}$. As for the glass waste sand $5 \%$ of the weight of $0.158 \mathrm{~kg}$, $7.5 \%$ glass waste of $0.237 \mathrm{~kg}$.

\section{Compressive Strength Testing:}

Testing the compressive strength of concrete is done when the concrete was 7 days, 14 days and 28 days, using a press machine with a capacity of $1500 \mathrm{KN}$, the specimen to be tested is a cylinder with a diameter of $15 \mathrm{~cm}$ and 30 $\mathrm{cm}$ high and the number of different test as many as 54 fruit, with the grouping of the test object in accordance with the variation thereof.Here are the results of compressive strength of concrete:

\section{Concrete Compressive Strength Normal:}

Table 4:- Results of normal concrete compressive strength test. 


\begin{tabular}{|c|c|c|c|c|}
\hline \multicolumn{5}{|c|}{ Age 7 days } \\
\hline $\begin{array}{c}\text { Test } \\
\text { objects }\end{array}$ & $\begin{array}{l}\text { Press load } \\
\text { testing } \\
\text { (Ton) }\end{array}$ & $\begin{array}{l}\text { style Press } \\
\text { (P) } \\
\text { (N) }\end{array}$ & $\begin{array}{c}\mathrm{A}=17671.5 \mathrm{~mm}^{2} \\
f^{\prime} c=(\mathrm{P} / \mathrm{A}) \\
(\mathrm{MPa})\end{array}$ & $\begin{array}{c}\text { Estimated } 28 \text { days } \\
f^{\prime} c / 0.65 \\
(\mathrm{MPa})\end{array}$ \\
\hline 1 & 30 & 300000 & 16.98 & 26.12 \\
\hline 2 & 30 & 300000 & 16.98 & 26.12 \\
\hline 3 & 31.5 & 315000 & 17.83 & 27.42 \\
\hline & & Average & 17.26 & 26.55 \\
\hline \multicolumn{5}{|c|}{ Age 14 days } \\
\hline $\begin{array}{c}\text { Test } \\
\text { objects }\end{array}$ & $\begin{array}{l}\text { Press load } \\
\text { testing } \\
\text { (Ton) } \\
\end{array}$ & $\begin{array}{l}\text { style Press } \\
(\mathrm{P}) \\
(\mathrm{N}) \\
\end{array}$ & $\begin{array}{c}\mathrm{A}=17671.5 \mathrm{~mm}^{2} \\
f^{\prime} c=(\mathrm{P} / \mathrm{A}) \\
(\mathrm{MPa})\end{array}$ & $\begin{array}{c}\text { Estimated } 28 \text { days } \\
f^{\prime} c / 0.88 \\
(\mathrm{MPa})\end{array}$ \\
\hline 1 & 40.5 & 405000 & 22.92 & 26.04 \\
\hline 2 & 42 & 420000 & 23.77 & 27.01 \\
\hline 3 & 40.5 & 405000 & 22.92 & 26.04 \\
\hline & & Average & 23.20 & 26.36 \\
\hline \multicolumn{5}{|c|}{28 days } \\
\hline $\begin{array}{c}\text { Test } \\
\text { objects }\end{array}$ & $\begin{array}{l}\text { Press load } \\
\text { testing } \\
\text { (Ton) }\end{array}$ & $\begin{array}{c}\text { style Press } \\
\text { (P) } \\
(\mathrm{kg})\end{array}$ & $\begin{array}{c}\mathrm{A}=17671.5 \mathrm{~mm}^{2} \\
f^{\prime} c=(\mathrm{P} / \mathrm{A}) \\
(\mathrm{MPa})\end{array}$ & $\begin{array}{c}\text { Estimated } 28 \text { days } \\
f^{\prime} c / 1.00 \\
(\mathrm{MPa})\end{array}$ \\
\hline 1 & 46.5 & 465000 & 26.31 & 26.31 \\
\hline 2 & 46.5 & 465000 & 26.31 & 26.31 \\
\hline 3 & 45 & 450000 & 25.46 & 25.46 \\
\hline & & Average & 26.03 & 26.03 \\
\hline
\end{tabular}

Based on the compressive strength test results, obtained average value of compressive strength of normal concrete age of 7 days was $17.26 \mathrm{MPa}$, aged 14 days was $23.20 \mathrm{MPa}$, and while the age of 28 days was $26.03 \mathrm{MPa}$.

Mixed Concrete Compressive Strength Waste Carbide 7\%:

Table 5:- Results of testing the compressive strength of concrete with mixed waste carbide 7\%.

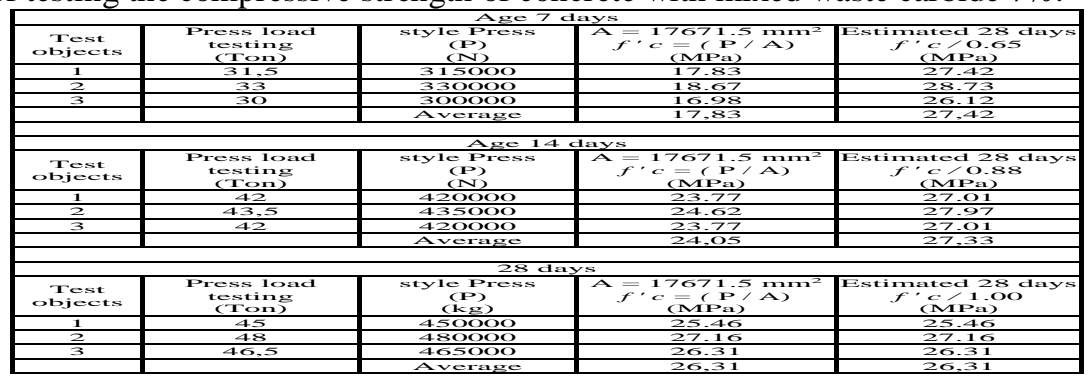

Based on the compressive strength test results, obtained an average value of compressive strength of concrete with mixed waste carbide $7 \%$ for those aged 7 days was $17.83 \mathrm{MPa}$, aged 14 days was $24.05 \mathrm{MPa}$, and while the age of 28 days was $26.31 \mathrm{MPa}$.

Mixed Concrete Compressive Strength Waste Carbide 10\%:

Table 6: Results of testing the compressive strength of concrete with a mixture of $10 \%$ calcium carbide waste. 


\begin{tabular}{|c|c|c|c|c|}
\hline \multicolumn{5}{|c|}{ Age 7 days } \\
\hline $\begin{array}{c}\text { Test } \\
\text { objects }\end{array}$ & $\begin{array}{l}\text { Press load } \\
\text { testing } \\
\text { (Ton) }\end{array}$ & $\begin{array}{l}\text { style Press } \\
\text { (P) } \\
\text { (N) }\end{array}$ & $\begin{array}{c}\mathrm{A}=17671.5 \mathrm{~mm}^{2} \\
f^{\prime} c=(\mathrm{P} / \mathrm{A}) \\
(\mathrm{MPa})\end{array}$ & $\begin{array}{c}\text { Estimated } 28 \text { days } \\
f^{\prime} c / 0.65 \\
(\mathrm{MPa})\end{array}$ \\
\hline 1 & 33 & 330000 & 18.67 & 28.73 \\
\hline 2 & 33 & 330000 & 18.67 & 28.73 \\
\hline 3 & 31,5 & 315000 & 17.83 & 27.42 \\
\hline & & Average & 18,39 & 28,29 \\
\hline \multicolumn{5}{|c|}{ Age 14 days } \\
\hline $\begin{array}{c}\text { Test } \\
\text { objects }\end{array}$ & $\begin{array}{c}\text { Press load } \\
\text { testing } \\
\text { (Ton) } \\
\end{array}$ & $\begin{array}{c}\text { style Press } \\
(\mathrm{P}) \\
(\mathrm{N}) \\
\end{array}$ & $\begin{array}{c}\mathrm{A}=17671.5 \mathrm{~mm}^{2} \\
f^{\prime} c=(\mathrm{P} / \mathrm{A}) \\
(\mathrm{MPa})\end{array}$ & \begin{tabular}{|c|} 
Estimated 28 days \\
$f^{\prime} c / 0.88$ \\
$(\mathrm{MPa})$ \\
\end{tabular} \\
\hline 1 & 42 & 420000 & 23.77 & 27.01 \\
\hline 2 & 45 & 450000 & 25.46 & 28.94 \\
\hline 3 & 43,5 & 435000 & 24.62 & 27.97 \\
\hline & & Average & 24,62 & 27,97 \\
\hline \multicolumn{5}{|c|}{28 days } \\
\hline $\begin{array}{c}\text { Test } \\
\text { objects }\end{array}$ & $\begin{array}{c}\text { Press load } \\
\text { testing } \\
\text { (Ton) } \\
\end{array}$ & $\begin{array}{c}\text { style Press } \\
(\mathrm{P}) \\
(\mathrm{kg}) \\
\end{array}$ & $\begin{array}{c}\mathrm{A}=17671.5 \mathrm{~mm}^{2} \\
f^{\prime} c=(\mathrm{P} / \mathrm{A}) \\
(\mathrm{MPa})\end{array}$ & $\begin{array}{c}\text { Estimated } 28 \text { days } \\
f^{\prime} c / 1.00 \\
(\mathrm{MPa}) \\
\end{array}$ \\
\hline 1 & 45 & 450000 & 25.46 & 25.46 \\
\hline 2 & 48 & 480000 & 27.16 & 27.16 \\
\hline 3 & 48 & 480000 & 27.16 & 27.16 \\
\hline & & Average & 26,60 & 26,60 \\
\hline
\end{tabular}

Based on the compressive strength test results, obtained an average value of compressive strength of concrete with mixed waste carbide $10 \%$ for those aged 7 days was $18.39 \mathrm{MPa}$, aged 14 days was $24.62 \mathrm{MPa}$, and while the age of 28 days was $26.60 \mathrm{MPa}$.

Mixed Concrete Compressive Strength Glass Waste 5\%

Table 7:- Results of testing the compressive strength of concrete with a mixture of $5 \%$ of glass waste.

\begin{tabular}{|c|c|c|c|c|}
\hline \multicolumn{5}{|c|}{ Age 7 days } \\
\hline $\begin{array}{c}\text { Test } \\
\text { objects }\end{array}$ & $\begin{array}{c}\text { Press load } \\
\text { tessing } \\
(\text { Ton) }\end{array}$ & $\begin{array}{c}\text { style Press } \\
(\mathrm{P}) \\
(\mathrm{N})\end{array}$ & $\begin{array}{c}\mathrm{A}=17671.5 \mathrm{~mm}^{2} \\
f^{\prime} c=(\mathrm{P} / \mathrm{A}) \\
(\mathrm{MPa})\end{array}$ & $\begin{array}{c}\text { Estimated 28 days } \\
f^{\prime} \mathrm{c} / 0.65 \\
(\mathrm{MPa})\end{array}$ \\
\hline 1 & 30 & 300000 & 16.98 & 26.12 \\
\hline 2 & 33 & 330000 & 18.67 & 28.73 \\
\hline 3 & 30 & 300000 & 16.98 & 26.12 \\
\hline & & Average & 17.54 & 26.99 \\
\hline
\end{tabular}




\begin{tabular}{|c|c|c|c|c|}
\hline \multicolumn{5}{|c|}{ Age 14 days } \\
\hline $\begin{array}{c}\text { Test } \\
\text { objects }\end{array}$ & $\begin{array}{l}\text { Press load } \\
\text { testing } \\
\text { (Ton) }\end{array}$ & $\begin{array}{l}\text { style Press } \\
(\mathrm{P}) \\
(\mathrm{N})\end{array}$ & $\begin{array}{c}\mathrm{A}=17671.5 \mathrm{~mm}^{2} \\
f^{\prime} c=(\mathrm{P} / \mathrm{A}) \\
(\mathrm{MPa})\end{array}$ & $\begin{array}{c}\text { Estimated } 28 \text { days } \\
f^{\prime} c / 0.88 \\
(\mathrm{MPa})\end{array}$ \\
\hline 1 & 40.5 & 405000 & 22.92 & 26.04 \\
\hline 2 & 42 & 420000 & 23.77 & 27.01 \\
\hline 3 & 42 & 420000 & 23.77 & 27.01 \\
\hline & & Average & 23.49 & 26.69 \\
\hline \multicolumn{5}{|c|}{28 days } \\
\hline $\begin{array}{c}\text { Test } \\
\text { objects }\end{array}$ & $\begin{array}{l}\text { Press load } \\
\text { testing } \\
\text { (Ton) }\end{array}$ & $\begin{array}{c}\text { style Press } \\
(\mathrm{P}) \\
(\mathrm{kg})\end{array}$ & $\begin{array}{c}\mathrm{A}=17671.5 \mathrm{~mm}^{2} \\
f^{\prime} c=(\mathrm{P} / \mathrm{A}) \\
(\mathrm{MPa})\end{array}$ & $\begin{array}{c}\text { Estimated } 28 \text { days } \\
f^{\prime} c / 1.00 \\
(\mathrm{MPa})\end{array}$ \\
\hline 1 & 46.5 & 465000 & 26.31 & 26.31 \\
\hline 2 & 46.5 & 465000 & 26.31 & 26.31 \\
\hline 3 & 45 & 450000 & 25.46 & 25.46 \\
\hline & & Average & 26.03 & 26.03 \\
\hline
\end{tabular}

Based on the compressive strength test results, obtained an average value of compressive strength of concrete with a mixture of glass waste $5 \%$ for those aged 7 days was $17.54 \mathrm{MPa}$, aged 14 days was $23.49 \mathrm{MPa}$, and while the age of 28 days was $26.03 \mathrm{MPa}$.

\section{Mixed Concrete Compressive Strength 7.5\% Waste Glass}

Table 8:- Results of testing the compressive strength of concrete with a mixture of glass waste $7.5 \%$.

\begin{tabular}{|c|c|c|c|c|}
\hline \multicolumn{5}{|c|}{ Age 7 days } \\
\hline $\begin{array}{c}\text { Test } \\
\text { objects }\end{array}$ & $\begin{array}{l}\text { Press load } \\
\text { testing } \\
\text { (Ton) } \\
\end{array}$ & $\begin{array}{l}\text { style Press } \\
(\mathrm{P}) \\
(\mathrm{N}) \\
\end{array}$ & $\begin{array}{c}\mathrm{A}=17671.5 \mathrm{~mm}^{2} \\
f^{\prime} c=(\mathrm{P} / \mathrm{A}) \\
(\mathrm{MPa})\end{array}$ & $\begin{array}{c}\text { Estimated } 28 \text { days } \\
f^{\prime} c / 0.65 \\
(\mathrm{MPa})\end{array}$ \\
\hline 1 & 31.5 & 315000 & 17.83 & 27.42 \\
\hline 2 & 30 & 300000 & 16.98 & 26.12 \\
\hline 3 & 33 & 330000 & 18.67 & 28.73 \\
\hline & & Average & 17.83 & 27.42 \\
\hline \multicolumn{5}{|c|}{ Age 14 days } \\
\hline $\begin{array}{c}\text { Test } \\
\text { objects }\end{array}$ & $\begin{array}{l}\text { Press load } \\
\text { testing } \\
\text { (Ton) }\end{array}$ & $\begin{array}{l}\text { style Press } \\
(\mathrm{P}) \\
(\mathrm{N})\end{array}$ & $\begin{array}{c}\mathrm{A}=17671.5 \mathrm{~mm}^{2} \\
f^{\prime} c=(\mathrm{P} / \mathrm{A}) \\
(\mathrm{MPa})\end{array}$ & $\begin{array}{c}\text { Estimated } 28 \text { days } \\
f^{\prime} c / 0.88 \\
(\mathrm{MPa})\end{array}$ \\
\hline 1 & 40.5 & 405000 & 22.92 & 26.04 \\
\hline 2 & 43.5 & 435000 & 24.62 & 27.97 \\
\hline 3 & 42 & 420000 & 23.77 & 27.01 \\
\hline & & Average & 23.77 & 26.36 \\
\hline \multicolumn{5}{|c|}{28 days } \\
\hline $\begin{array}{c}\text { Test } \\
\text { objects }\end{array}$ & $\begin{array}{l}\text { Press load } \\
\text { testing } \\
\text { (Ton) }\end{array}$ & $\begin{array}{l}\text { style Press } \\
(\mathrm{P}) \\
(\mathrm{kg})\end{array}$ & $\begin{array}{c}\mathrm{A}=17671.5 \mathrm{~mm}^{2} \\
f^{\prime} c=(\mathrm{P} / \mathrm{A}) \\
(\mathrm{MPa})\end{array}$ & $\begin{array}{c}\text { Estimated } 28 \text { days } \\
f^{\prime} c / 1.00 \\
(\mathrm{MPa})\end{array}$ \\
\hline 1 & 45 & 450000 & 25.46 & 25.46 \\
\hline 2 & 46.5 & 465000 & 26.31 & 26.31 \\
\hline 3 & 46.5 & 465000 & 26.31 & 26.31 \\
\hline & & Average & 26.03 & 26.03 \\
\hline
\end{tabular}

Based on the compressive strength test results, obtained an average value of compressive strength of concrete with a mixture of glass waste $7.5 \%$ for those aged 7 days was $17.83 \mathrm{MPa}$, aged 14 days was $23.20 \mathrm{MPa}$, and while 28 days is $26.03 \mathrm{MPa}$. 
Mixed Concrete Compressive Strength Combination Carbide Hazardous Waste Glass $10 \%+7.5 \%$

Table 9:- Results of testing the compressive strength of concrete with a mixed combination of carbide waste glass waste $10 \%+7.5 \%$.

\begin{tabular}{|c|c|c|c|c|}
\hline \multicolumn{5}{|c|}{ Age 7 days } \\
\hline $\begin{array}{c}\text { Test } \\
\text { objects }\end{array}$ & $\begin{array}{l}\text { Press load } \\
\text { testing } \\
\text { (Ton) }\end{array}$ & $\begin{array}{l}\text { style Press } \\
\text { (P) } \\
\text { (N) }\end{array}$ & $\begin{array}{c}\mathrm{A}=17671.5 \mathrm{~mm}^{2} \\
f^{\prime} c=(\mathrm{P} / \mathrm{A}) \\
(\mathrm{MPa})\end{array}$ & $\begin{array}{c}\text { Estimated } 28 \text { days } \\
f^{\prime} c / 0.65 \\
(\mathrm{MPa})\end{array}$ \\
\hline 1 & 31.5 & 315000 & 17.83 & 27.42 \\
\hline 2 & 31.5 & 315000 & 17.83 & 27.42 \\
\hline 3 & 33 & 330000 & 18.67 & 28.73 \\
\hline & & Average & 18.11 & 27.86 \\
\hline \multicolumn{5}{|c|}{ Age 14 days } \\
\hline $\begin{array}{c}\text { Test } \\
\text { objects }\end{array}$ & $\begin{array}{l}\text { Press load } \\
\text { testing } \\
\text { (Ton) }\end{array}$ & $\begin{array}{l}\text { style Press } \\
\text { (P) } \\
(\mathrm{N})\end{array}$ & $\begin{array}{c}\mathrm{A}=17671.5 \mathrm{~mm}^{2} \\
f^{\prime} c=(\mathrm{P} / \mathrm{A}) \\
(\mathrm{MPa})\end{array}$ & $\begin{array}{c}\text { Estimated } 28 \text { days } \\
f^{\prime} c / 0.88 \\
(\mathrm{MPa}) \\
\end{array}$ \\
\hline 1 & 42 & 420000 & 23.77 & 27.01 \\
\hline 2 & 42 & 420000 & 23.77 & 27.01 \\
\hline 3 & 45 & 450000 & 25.46 & 28.94 \\
\hline & & Average & 24.33 & 27.65 \\
\hline \multicolumn{5}{|c|}{28 days } \\
\hline $\begin{array}{c}\text { Test } \\
\text { objects }\end{array}$ & $\begin{array}{l}\text { Press load } \\
\text { testing } \\
\text { (Ton) }\end{array}$ & $\begin{array}{l}\text { style Press } \\
\text { (P) } \\
(\mathrm{kg})\end{array}$ & $\begin{array}{c}\mathrm{A}=17671.5 \mathrm{~mm}^{2} \\
f^{\prime} c=(\mathrm{P} / \mathrm{A}) \\
(\mathrm{MPa})\end{array}$ & $\begin{array}{c}\text { Estimated } 28 \text { days } \\
f^{\prime} c / 1.00 \\
(\mathrm{MPa})\end{array}$ \\
\hline 1 & 46.5 & 465000 & 26.31 & 26.31 \\
\hline 2 & 48 & 480000 & 27.16 & 27.16 \\
\hline 3 & 45 & 450000 & 25.46 & 25.46 \\
\hline & & Average & 26.31 & 26.31 \\
\hline
\end{tabular}

Based on the compressive strength test results, obtained an average value of compressive strength of concrete with a mixed combination of carbide waste glass waste $10 \%+7.5 \%$ for those aged 7 days was 18.11 MPa, aged 14 days was $24.33 \mathrm{MPa}$, and while age 28 days is $26.31 \mathrm{MPa}$.

\section{Discussion:-}

If we compare between the compressive strength of normal concrete with concrete using a mixture of $7 \%$ of waste carbide, carbide waste $10 \%, 5 \%$ glass waste, glass waste $7.5 \%$ and a combination of calcium carbide waste glass waste $10 \%+7.5 \%$ for the concrete 7,14 and 28 days, then we can see an increase or not, on the compressive strength of the concrete mix materials used at each percentage of variation.

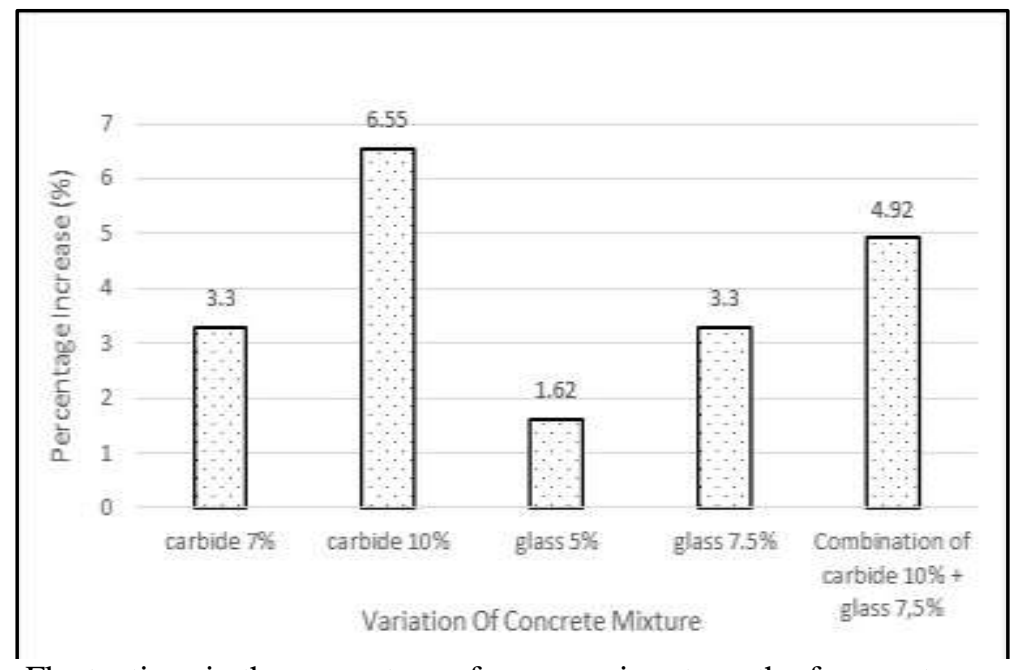

Figure 3:- Fluctuations in the percentage of compressive strength of concrete age of 7 days. 


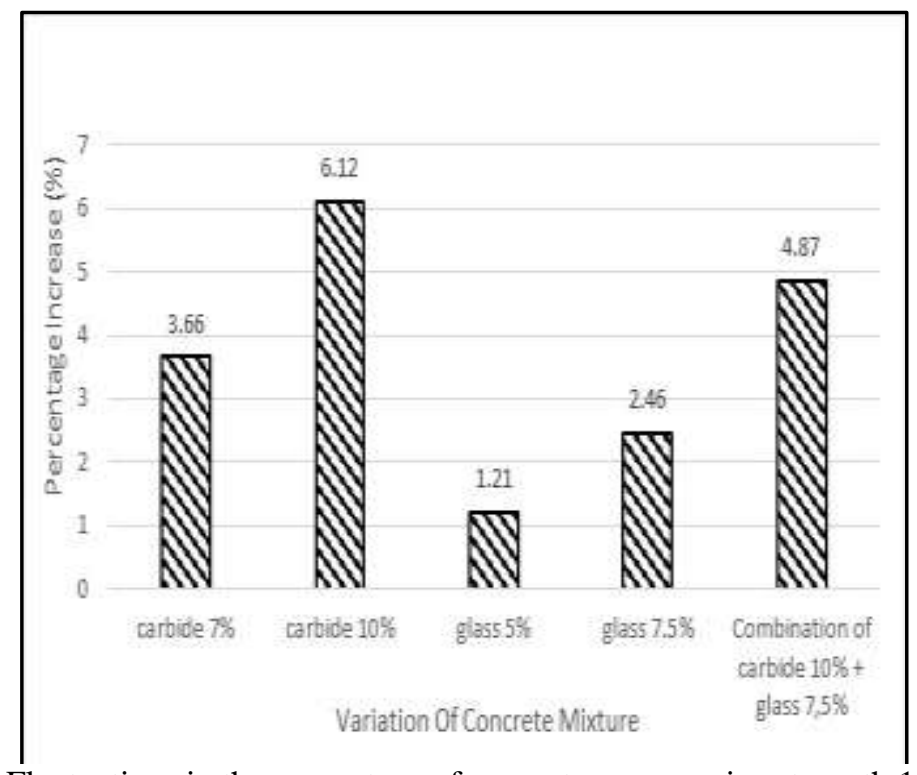

Figure 4:- Fluctuations in the percentage of concrete compressive strength 14 days old.

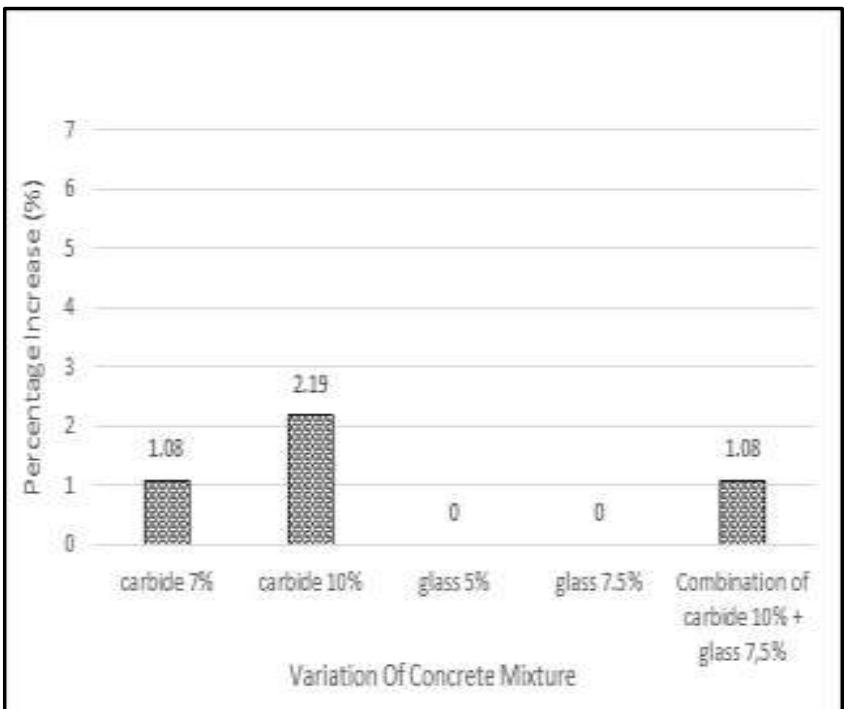

Figure 5:- Fluctuations in the percentage of compressive strength of concrete age of 28 days.

From Figure 3 to Figure 5 it can be seen that the mixture of waste carbide variation of $10 \%$ of the most consistent increases, the percentage of $6.55 \%$ at the age of 7 days, amounting to $6.12 \%$ at 14 days, and amounted to $2.19 \%$ at 28 days of normal concrete, the glass waste mix variations optimum compressive strength is on a variation of $7.5 \%$, amounting to $3.30 \%$ at the age of 7 days, amounting to $2.46 \%$ at 14 days of normal concrete, but at 28 days did not increase, but the value is still in accordance with the quality of concrete plans at $25 \mathrm{MPa}$. While the mixture variation combinations carbide waste glass waste $10 \%$ to $7.5 \%$, an increase in the amount of $4.92 \%$ at the age of 7 days, amounting to $4.87 \%$ at 14 days, and $1.08 \%$ at 28 days of normal concrete.

\section{Conclusion:-}

From the research and testing of compressive strength of concrete ages 7, 14 and 28 days, it can be drawn several conclusions, among others:

Based on the concrete compressive strength test data, waste carbide with a variation of $10 \%$ consistently increased, amounting to $6.55 \%$ at the age of 7 days, amounting to $6.12 \%$ at 14 days, and amounted to $2.19 \%$ at 28 days, at glass waste mix variations optimum compressive strength is on a variation of $7.5 \%$, amounting to $3.30 \%$ at the age 
of 7 days, amounting to $2.46 \%$ at 14 days of normal concrete, but at the age of 28 days is not increased, but its value is still in accordance with a plan of concrete quality.

Based on the concrete compressive strength test data, mixture combinations carbide waste glass waste $10 \%+7.5 \%$, an increase in the amount of $4.92 \%$ at the age of 7 days, amounting to $4.87 \%$ at 14 days, and $1.08 \%$ at 28 days, compared with normal concrete. And this proves that the carbide waste and glass waste can be a substitution of alternative materials cement and sand in concrete mixes with a certain variation.

\section{References:-}

1. Damara, B. (2018). Pengaruh Penambahan Limbah B3 Pada Kuat Tekan Beton Mutu K-175. Jurnal Teknik Sipil, Universitas Islam Lamongan.3(1):100-107.

2. Faisal, A. (2013). Panduan Penulisan Skripsi Mahasiswa S1 Program Studi Teknik Sipil. Medan: Universitas Muhammadiyah Sumatera Utara.

3. Rajiman. (2015). Pengaruh Penambahan Limbah Karbit dan Material Agregat Alam (Feldspart) Terhadap Sifat Fisik Beton. Lampung: Dosen Program Studi Teknik Sipil, Universitas Sang Bumi Ruwa Jurai.

4. Harahap, S. R. (2018). Kombinasi Filler Abu Ampas Tebu Dan Botol Kaca Substitusi Pasir (Studi Penelitian). Laporan Tugas Akhir. Medan: Program Studi Teknik Sipil, Universitas Muhammadiyah Sumatera Utara.

5. SNI 03-2834. (2000). Tata cara pembuatan rencana campuran beton normal. Bandan Standardisasi Nasional

6. SNI 1972. (2008). Cara Uji Slump Beton. Bandan Standardisasi Nasional

7. SNI 1974. (2011). Cara uji kuat tekan beton dengan benda uji silinder. Bandan Standardisasi Nasional.

8. SNI 2417. (2008). Cara uji keausan agregat dengan mesin abrasi Los Angeles. Bandan Standardisasi Nasional.

9. Suhartini, A. (2014). Pengaruh Penambahan Tumbukan Limbah Botol Kaca Sebagai Bahan Substitusi Agregat Halus Terhadap Kuat Tekan dan Kuat Lentur Beton. Jurnal Beton. Universitas Islam 45 Bekasi 2(1):66-80.

10. Engineering, Islamic University Lamongan. 3 (1): 100-107.

11. Faisal, A. (2013). Free Thesis Writing Students S1 Civil Engineering Program. Terrain: North Sumatra Muhammadiyah University.

12. Rajiman. (2015). Effect of Adding Waste Material Carbide and Natural Aggregate (Feldspart) Against Physical Properties of Concrete. Lampung: Lecturer in Civil Engineering Program, University Sang Bumi Ruwa Jurai.

13. Harahap, SR (2018). Filler combination Abu Dregs Cane And Sand Glass Bottle Substitution (Research Study). Final report. Terrain: Civil Engineering Program, University of North Sumatra Muhammadiyah.

14. SNI 03-2834. (2000). The procedure for making a plan of normal concrete mix. Bandan National Standardization

15. ISO 1972 (2008). Concrete Slump Test Method. Bandan National Standardization

16. ISO 1974 (2011). Test method for compressive strength of concrete with the cylindrical test object.Bandan National Standardization,

17. SNI 2417. (2008). Test method with engine aggregate abrasion wear of Los Angeles.Bandan National Standardization,

18. Suhartini, A. (2014). Effect of Addition collision Waste Glass Bottles For Fine Aggregate Materials substitution and Strong Against Bending Compressive Strength Concrete. Concrete Journal. Universitas Islam 45 Bekasi 2 (1): 66-80. 